\section{Water Resources of Great Britain}

Mr. H. U. WILIINK, Minister of Health, in a statement in the House of Commons on February 10 , said that the Government proposes as part of its general reconstruction programme to introduce legislation making possible further Exchequer assistance for the extension of piped water supplies in rural localities. This will apply also to sewerage in such areas. A White Paper is in preparation outlining the Government's general proposals with regard to water ; these will include provision for an adequate scientific assessment of resources and for the control and co-ordination of their use and distribution. It is hoped to issue the White Paper about the same time as the introduction of the Bill. It will deal with schemes on national lines.

\section{Standardization of Non-lonizing Radiations}

THE Medical Research Council has appointed the following committee to advise and assist in promoting the quantitative study of the non-ionizing radiations, particularly in relation to their medical applications: Prof. H. Hartridge (chairman), Mr. P. Bauwens, Dr. R. B. Bourdillon, Mr. E. Rock Carling, Prof. J. A. Carroll, Mr. J. Guild (nominated by the Department of Scientific and Industrial Research), Prof. F. L. Hopwood and Prof. W. V. Mayneord (secretary). In 1928 and 1937 satisfactory units for the measurement of ionizing radiations were agreed internationally, and there is urgent need of a corresponding standardization for the non-ionizing radiations. Under this heading will be included infra-red, visible and short-wave wireless radiations, but it may be found advisable to deal also with ultra-violet and ultrasonic radiations, since none of these was covered by the earlier recommendations.

\section{Transmission and Distribution of Electricity in Mines}

A PAPER on this subject was read before the Institution of Electrical Engineers in London on February 9 by B. L. Metcalf. In the South Wales coalfield, where approximately 16 per cent of the total output of Great Britain is raised, the transmission and distribution of electricity introduces special problems owing to the hilly nature of the country. To give some idea of the potential demand at collieries to be obtained, the load for a typical group of collieries is analysed. Some notes are included on the choice of switchgear for collieries and on the influence on this choice of the proposed amendments to the Regulations for the Use of Electricity in Mines. Information is given regarding the damage to trans mission towers during the ice storm of 1940 , and a proposal is made to amend the regulations of the Electricity Commissioners governing ice-loading for conductors. A new design of cross-arm for a singleeircuit $33-\mathrm{kV}$. overhead line is illustrated. Recom. mendations are made for the standardization of equipment required for the electrification of collieries.

The magnitude of the potential colliery electrical load should be given full consideration in any plan for the generation, transmission and distribution of electricity in any industrial mining area. Electrification of the collieries in any area would be simplified and cheapened by greater standardization of the sizes of units adopted. Standardization could be applied with advantage to switchgear, transformers, compressors, haulages, winder drums, transmission- line cross-arms, cable sizes, voltages, etc. The subject of pit-head generation is touched on only as it affects the general problems of transmission and distribution, but it is one which demands full and thorough teehnical investigation in all its aspects, and in relation to the location of washeries, existing generating stations and transmission lines, coal freights and other local industrial loads.

\section{Man's Influence on Seismic Movements}

WaLter Kroche has an article with the title "La Accion Humana Como Una Causa Posible De Liberar Movimientos Sismicos" in Anales de la Sociedad Cientifica Argentina (135, Ent. IV and V, 1-41; 1943) which suggests a number of ways in which the progress of civilization can influence earth movements. A few of these will be referred to in the following brief summary. The weight of matter transported by the great rivers and deposited at their mouths depends on the denudation which takes place, and this, in turn, depends on the nature of the soil, the presence of vegetation, and other factors which are under the control of man. Variations in isostasy in the deltas of rivers as well as in the regions of denudation are, therefore, indirectly due to human agency. Then again it is pointed out that oscillations in the earth's axis might be produced by the displacements of matter through fluvial transportation, and this latter depends on man's interference with the vegetation. Another important factor is fires which destroy vegetation and so release a considerable weight over certain parts of the earth's crust. The loss of weight on land appears as an increase in the oceans, which receive a great portion of the burnt vegetation in the form of carbon and water. The weight of great cities with their inhabitants, such as San Francisco and Tokyo, is able to originate earth movements, more especially in those regions of the earth where there is a certain amount of instability. It seems possible to conduct research on the influence of re-afforestation in mitigating the danger of denudation and devastation on the earth's surface, and in this way to estimate the extent of the human factor in the production of earth disturbances.

\section{The Dominion Observatory, Wellington}

THE report for the year ended December 31, 1942, of the Dominion Observatory, Wellington (Bull. No. $R 28$ ) deals chiefly with time service and seismology. During most of the year the control of the time service was greatly facilitated, enabling additional check time signals to be received from Greenwich and Washington. The clocks were seriously affected by local earthquakes on June 24, August 2 and Decem. ber 2 , but they suffered no permanent damage. The free pendulum was frequently disturbed by local earthquakes, and investigations showed that marked changes of rate are not due to defects in the clock mechanism but are associated with one or other of the following causes: (1) violent fluctuations in barometric pressure; (2) changes in the direction of local ground tilt ; (3) local earthquakes. The severe outbreak of seismic activity in the Wairarapa district on June 24, 1942, followed by severe aftershocks on August 2 and December 2, has been already referred to, and a considerable number of subsidiary shocks also occurred, six hundred being recorded at Wellington. On June 27 a shock took place the epicentre of which was near White Island. The focal depth, 230 miles, was the deepest origin so far recorded in 